\title{
Uso de embalagem e da refrigeração no armazenamento de lichias "Bengal"
}

\author{
Use of packaging and refrigeration in the storage of "Bengal" litchi
}

\section{Rafael Bibiano FERREIRA ${ }^{1}$; Denis Henrique Silva NADALETI ${ }^{2}$; Bianca Sarzi de SOUZA ${ }^{3}$; Paulo Sérgio de SOUZA}

\author{
${ }^{1}$ Autor para correspondência. Mestrando, Universidade Estadual Paulista “Júlio de Mesquita Filho" UNESP, Câmpus de \\ Botucatu. Departamento de Horticultura. Fazenda Lageado Portaria I: Rua José Barbosa de Barros, no 1780, \\ aprigio_bibiano@hotmail.com \\ ${ }^{2}$ Eng. Agrônomo, IFSULDEMINAS - Campus Muzambinho, denishenriquesilva@yahoo.com.br \\ ${ }^{3}$ DSc. - Professora, IFSULDEMINAS - Campus Muzambinho, bianca.souza@muz.ifsuldeminas.edu.br \\ ${ }^{4}$ DSc. - Professor, IFSULDEMINAS - Campus Muzambinho, paulo.souza@muz.ifsuldeminas.edu.br
}

Recebido em: 17-04-2015; Aceito em: 15-03-2016

\begin{abstract}
The objective of this study was to evaluate the effect of packaging and refrigeration on the storage of "Bengal" litchi. Different packaging types were selected: expanded polystyrene trays covered with polyvinyl chloride film (PVC) (T1), polyethylene terephthalate tray (PET) with lid (T2) and absence of packaging (T3). After the selection, the material was split into two lots, where one packaging group was stored at room temperature, $25^{\circ} \mathrm{C}$, for a period of six days and the other group was stored under refrigeration at $5{ }^{\circ} \mathrm{C}$ for a period of nine days. Chemical, physical and sensory evaluations were performed every two days (room temperature) and every three days (refrigerated storage), the chemical evaluations being: $\mathrm{pH}$, titratable acidity (TA), soluble solids (SS), ascorbic acid content and SS/TA ratio; physical evaluations being: luminosity, chromaticity, hue angle and weight loss; and sensory evaluations being: appearance, purchase intention and consumer preference. PET packaging showed lower fresh weight loss for the fruits, in the temperatures tested throughout the experiment. PET and PVC packaging were efficient in preventing browning of fruits. The use of PET packaging and refrigeration in the storage of litchi provides better maintenance of the physical, chemical and sensory quality of fruits for up to 9 days.
\end{abstract}

Additional keywords: Litchi chinensis; postharvest conservation; shelf life.

\section{Resumo}

O objetivo do presente trabalho foi avaliar o efeito da embalagem e da refrigeração no armazenamento de lichia "Bengal". Foram selecionados diferentes tipos de embalagens: bandeja de poliestireno expandido recoberta com filme de cloreto de polivinila (PVC) (T1); bandeja de tereftalato de polietileno (PET) com tampa (T2), e ausência de embalagens (T3). Após a seleção, dividiu-se o material em dois lotes: um onde um grupo de embalagens foi armazenado em temperatura ambiente, a $25^{\circ} \mathrm{C}$, por um período de seis dias, e o outro grupo sob refrigeração a $5^{\circ} \mathrm{C}$, por um período de nove dias. A cada dois dias (ambiente) e a cada três dias (refrigerado), foram feitas avaliações químicas de $\mathrm{pH}$, teor de acidez titulável (AT), de sólidos solúveis (SS), teor de ácido ascórbico e da relação SS/AT; físicas de luminosidade, cromaticidade, ângulo Hue e perda de massa; e sensoriais quanto à aparência, intenção de compra e preferência do consumidor. A embalagem PET proporcionou menor perda de massa fresca pelos frutos, nas temperaturas testadas ao longo do experimento. As embalagens PET e PVC foram eficientes na prevenção do escurecimento dos frutos. O uso da embalagem PET e a refrigeração no armazenamento de lichias, proporcionam aos frutos melhor manutenção da qualidade física, química e sensorial dos frutos por até 9 dias.

Palavras-chave adicionais: conservação pós-colheita; Litchi chinensis; vida de prateleira.

\section{Introduction}

The litchi (Litchi chinensis Sonn) belongs to the family Sapindaceae and is originally from China. It has non-showy flowers, being creamy white-colored, and its tree reaches 10 to 12 meters high, its fruiting occurring from November to January (Martins, 2005).

Its fruits have reddish pericarp, translucent, nutritious and sweet pulp, and are classified as non- climacteric (Kumar et al., 2012; Liang et al., 2013). Due to the reddish color of the peel, the litchi is attractive to the consumer's eyes, however during storage at room temperature conditions, the concentration of anthocyanin, the pigment responsible for the red color of the fruits, reduces considerably (Lima et al., 2010).

These conditions result in browning of the pericarp of fruits, hindering its commercialization due to quality losses regarding its appearance. Notwith- 
standing, the pericarp browning causes little changes in the quality of the litchi pulp, though it leads to consumer rejection of the product (Lima et al., 2010).

An alternative to prolong the useful life of litchi and preserve its appearance is the use of different types of packaging associated with low temperatures. Using these methods, Somboonkaew \& Terry (2011) were able to preserve litchi fruits for up to 11 days, keeping the levels of anthocyanin, organic acids and sugars suitable during this period, indicating the efficiency of the system.

Based on these information, it was aimed with this work to evaluate the effect of packaging and refrigeration in the storage of "Bengal" litchi.

\section{Material and methods}

"Bengal" litchi fruits were used at the commercial maturation point, considered when the peel color was fully red, being selected those who had no mechanical damage or rotting on the surface. The fruits were acquired in a property located near the city of Monte Belo - MG.

From the original batch, three groups of fruits were formed, which were stored in the following packaging: expanded polystyrene trays covered with stretchable polyvinyl chloride film (PVC), with a thickness of $0.017 \mathrm{~mm}$ (T1), polyethylene terephthalate tray (PET) with lid (T2), and absence of packaging Control (T3). At this point, the packages were divided into two batches, performing two experiments separately. A packaging group was stored at room temperature, $25{ }^{\circ} \mathrm{C}$, for a period of 6 days, and the other group was stored under refrigeration at $5{ }^{\circ} \mathrm{C}$ for a period of 9 days. Every two days for the treatments stored at $25^{\circ} \mathrm{C}$ and every three days for the treatments stored at $5{ }^{\circ} \mathrm{C}$, the following assessments were performed: fresh weight loss: measured using a scale with $1200 \mathrm{~g}$ capacity and $0.1 \mathrm{~g}$ accuracy, where the loss was calculated from the difference between the final weight and the initial weight of the package; peel coloration: determined in 3 fruits through two readings, on opposite sides of their equatorial region, using a colorimeter (Minolta Chroma Meter CR-400), being reported by the parameters: luminosity, hue or color angle and chromaticity (Chroma); $\mathrm{pH}$; titratable acidity (TA); soluble solids (SS); ascorbic acid (AOAC, 2012), SS/TA ratio and overall appearance of the fruits that have been evaluated, according to a point scale, where 1 = great; 2 = good; 3 = regular; 4 = poor and $5=$ very poor. It was considered that the fruit was still suitable for sale until grade 3 . It was also performed a sensory evaluation in relation to the consumer preference through mixed hedonic scale of 5 points $(1=$ disliked extremely, 5 = liked extremely) (Meilgaard et al., 1999), to assess the fruits with respect to their appearance. The purchase intention was evaluated using a mixed structured scale of 5 points $(1=$ definitely would not buy; 2 = probably would not buy; 3 = maybe would buy/maybe not; 4 = probably would buy; 5 = certainly would buy) (Reis \& Minim, 2006).

The statistical design was completely randomized with 3 replications, having as experimental unit a package with 15 fruits. The experiment was a factorial $3 \times 3$, with 3 types of packaging and 3 sampling times for each of the storage conditions, at $25^{\circ} \mathrm{C}$ and $5{ }^{\circ} \mathrm{C}$. The mean values of the studied variables were analyzed using $\mathrm{F}$ test at $5 \%$ significance level, where the analysis of variance was carried out for the different treatments and evaluation periods. When significant, the means were compared by Tukey test at $5 \%$ probability.

\section{Results and discussions}

\section{Storage at room temperature}

It is verified with the $F$ test $(p<0.05)$ that there was no significant interaction between the packaging and the storage time for any of the experiments. Thus, the data on the physical, chemical and sensory characteristics evaluated were analyzed separately.

The fruits stored unpackaged showed greater weight loss, increased browning, indicated by the lower value of $L^{*}$ and chromaticity (Table 1$)$. These results corroborate Lima et al. (2010), who reported that the litchi fruits that showed greater visual darkening during storage were also the ones with the greatest weight loss, confirming the relationship between these factors. This darkening and the higher weight loss of fruits stored unpackaged had effects on the appearance, where this treatment reached grade 3 (regular), and also on consumer preference and purchase intent, since they had the lowest scores.

Fruits stored in PET packaging showed lower weight loss, higher chromaticity and received a good evaluation by consumers regarding the appearance, nonetheless, for consumer preference, the fruits of the polystyrene packaging covered with PVC film obtained better results (Table 1). It was not observed a significant difference between the packages in relation to luminosity, stating that the use of modified atmosphere in litchi storage controls or slows the browning. Thus, the effect of the package may have been effective in controlling the activity of enzymes related to fruit darkening. According to Kaushik et al. (2013), the main agents causing the litchi pericarp browning are the polyphenol oxidase (PPO) and peroxidase (POD) enzymes and the growth of microorganisms. Favorable results on the prevention of litchi browning were also found by Hajare et al. (2010), notwithstanding, with the use of refrigeration, indicating that the storage of fruits at $4{ }^{\circ} \mathrm{C}$ was effective in maintaining the $L$ values, regardless of the treatment.

Throughout the experiment at room temperature, there was a significant decrease in the values of luminosity $\left(L^{*}\right)$, indicating the browning of fruits (Table 1$)$. Hence, the appearance was impaired during storage, and after six days, the fruits were discarded because they reached grade 3 , not being considered suitable for marketing. 
Table 1 - Weight loss, luminosity $\left(L^{*}\right)$, color (Hue angle), chromaticity (Chroma), appearance, preference and purchase intention in litchi stored under different packaging at room temperature.

\begin{tabular}{|c|c|c|c|c|c|c|c|}
\hline Package & Weight Loss (\%) & $L^{*}$ & Hue & Chroma & Appearance & Preference & $\begin{array}{l}\text { Purchase } \\
\text { Intention }\end{array}$ \\
\hline PET & $0.40 \mathrm{C}$ & $41.58 \mathrm{~A}$ & 41.16 & $33.77 \mathrm{~A}$ & $1.78 \mathrm{~B}$ & $3.78 \mathrm{~B}$ & $3.35 \mathrm{~B}$ \\
\hline PVC & $3.32 \mathrm{~B}$ & $40.58 \mathrm{~A}$ & 45.37 & $30.50 \mathrm{~B}$ & $2.11 \mathrm{~B}$ & $4.43 \mathrm{~A}$ & $3.68 \mathrm{~A}$ \\
\hline NO PACKAGING & $17.19 \mathrm{~A}$ & $34.82 \mathrm{~B}$ & 48.17 & $25.18 \mathrm{C}$ & $3.33 \mathrm{~A}$ & $2.48 \mathrm{C}$ & $1.85 \mathrm{C}$ \\
\hline F Test & $207.28^{\star \star}$ & $27.05^{\star \star}$ & $2.90 \mathrm{NS}$ & $61.81^{\star *}$ & $18.11^{\star \star}$ & $149.97^{\star *}$ & $161.80^{* *}$ \\
\hline MSD (5\%) & 2.25 & 2.46 & 7.48 & 1.99 & 0.69 & 0.27 & 0.26 \\
\hline \multicolumn{8}{|l|}{ Time (Days) } \\
\hline 2 & 6.53 & $41.09 \mathrm{~A}$ & 46.38 & 31.04 & $1.55 \mathrm{~B}$ & 3.55 & 3.02 \\
\hline 4 & 6.53 & $38.05 \mathrm{~B}$ & 44.55 & 29.26 & $2.56 \mathrm{~A}$ & - & - \\
\hline 6 & 7.84 & $37.54 \mathrm{~B}$ & 4.76 & 29.15 & $3.11 \mathrm{~A}$ & 3.57 & 2.88 \\
\hline F Test & $1.48 \mathrm{NS}$ & $7.99^{\star *}$ & $0.42 \mathrm{NS}$ & $3.72 \mathrm{NS}$ & $16.78^{* \star}$ & $0.03 \mathrm{NS}$ & $2.30 \mathrm{NS}$ \\
\hline MSD (5\%) & 2.25 & 2.46 & 7.48 & 1.99 & 0.69 & 0.19 & 0.17 \\
\hline Pack. X Time & $0.88 \mathrm{NS}$ & $3.52^{*}$ & $0.82 \mathrm{NS}$ & $5.27^{\star *}$ & $3.94^{*}$ & 6.20 ** & $5.86^{* *}$ \\
\hline
\end{tabular}

Means followed by a same capital letter in the column, for each variable, do not differ significantly from each other $(P>0.05)$.

The soluble solids showed no effect of treatment nor of the storage period, being maintained at about $17^{\circ}$ Brix (Table 2). These values are close to those found by Hajare et al. (2010), where the soluble solids values for the litchi varieties "Shahi" and "China" were $17.1^{\circ}$ Brix after 12 days of storage.

It was observed effect of treatments on the titratable acidity values, where the fruits stored unpackaged showed the highest values (Table 2). It was also found that these levels decreased significantly during storage. The reduction of the titratable acidity values over the days was also observed by Silva et al. (2012), Liang et al. (2013) and Salomão et al. (2012), in litchi, regardless of the treatment used.

Also in Table 2, it was found that the SS/TA ratio was not affected by the treatments, but there was effect of the storage time in this parameter, with an increase in values. This behavior was also observed by Hojo et al. (2011) and reflected the decrease in the titratable acidity levels.

The treatments did not show significant differences between the $\mathrm{pH}$ values. Similar results were found by Silva et al. (2010) in a experiment with
"Bengal" litchi immersed in different doses of ascorbic acid and packed in polystyrene trays in a cold chamber at $5{ }^{\circ} \mathrm{C}$. There were significant changes in the $\mathrm{pH}$ values of the treatments in the first and second day of tests. This time effect was also observed by Kumar et al. (2012) in studies with the litchi varieties "China" and "Shahi".

There was no significant difference between the packages in relation to the ascorbic acid content, but there was a considerable decrease thereof between the second and third day of evaluation for all packages (Table 2). Such statements meet the results of Matias et al. (2012), where in tests with fruits of the cultivar "Bengal", it was reported that the ascorbic acid content decreased over time in all treatments. This decrease of the values in function of time was also observed by Liu et al. (2011), where the fruits subjected to 10,20 and 30 days of storage showed an average content of $23.7,20.7$ and 14.9 $\mathrm{mg}$ per $100 \mathrm{~g}$. The biochemical processes that occur after maturation are the main responsibles for the decrease of the ascorbic acid content in food, causing them to decay (Pandey et al., 2013).

Table 2 - Soluble solids (SS) content, titratable acidity (TA) SS/TA ratio, $\mathrm{pH}$ and ascorbic acid (AA) in litchi stored under different packaging at room temperature.

\begin{tabular}{|c|c|c|c|c|c|}
\hline Package & $\begin{array}{c}\text { SS } \\
\text { (Bix) }\end{array}$ & $\begin{array}{c}\text { TA } \\
\left(\mathrm{g} 100 \mathrm{~g}^{-1}\right)\end{array}$ & SS/TA & $\mathrm{pH}$ & 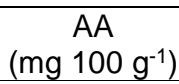 \\
\hline PET & 17.44 & $0.52 \mathrm{~B}$ & 34.38 & 4.11 & 79.64 \\
\hline $\begin{array}{l}\text { PVC } \\
\text { NO PACKAGING }\end{array}$ & $\begin{array}{l}16.99 \\
17.45\end{array}$ & $\begin{array}{l}0.53 \mathrm{~B} \\
0.59 \mathrm{~A}\end{array}$ & $\begin{array}{l}33.26 \\
31.02\end{array}$ & $\begin{array}{l}4.11 \\
4.06\end{array}$ & $\begin{array}{l}76.58 \\
83.26\end{array}$ \\
\hline $\begin{array}{l}\text { F Test } \\
\text { MSD (5\%) }\end{array}$ & $\begin{array}{l}1.74 \mathrm{NS} \\
0.65\end{array}$ & $\begin{array}{l}7.02^{\star \star} \\
0.06\end{array}$ & $\begin{array}{l}2.79 \mathrm{NS} \\
3.69\end{array}$ & $\begin{array}{l}1.00 \mathrm{NS} \\
0.10\end{array}$ & $\begin{array}{l}2.27 \mathrm{NS} \\
7.84\end{array}$ \\
\hline \multicolumn{6}{|l|}{ Time (Days) } \\
\hline 2 & 17.16 & $0.59 \mathrm{~A}$ & $24.95 B$ & $4.00 \mathrm{~B}$ & $84.17 \mathrm{~A}$ \\
\hline 4 & 17.27 & $0.46 \mathrm{~B}$ & $37.96 \mathrm{~A}$ & $4.12 \mathrm{~A}$ & $83.78 \mathrm{~A}$ \\
\hline 6 & 17.14 & 0.48 B & $35.74 \mathrm{~A}$ & $4.15 \mathrm{~A}$ & $71.51 \mathrm{~B}$ \\
\hline F Test & $0.16 \mathrm{NS}$ & $71.05^{* \star}$ & $46.26^{* *}$ & $8.75^{* \star}$ & $0.00^{\star \star}$ \\
\hline MSD (5\%) & 0.65 & 0.06 & 3.69 & 0.10 & 7.84 \\
\hline Pack. X Time & $1.35 \mathrm{NS}$ & $1.72 \mathrm{NS}$ & $0.53 \mathrm{NS}$ & $1.07 \mathrm{NS}$ & 3.98 * \\
\hline
\end{tabular}

Means followed by a same capital letter in the column, for each variable, do not differ significantly from each other $(\mathrm{P}>0.05)$. 


\section{Refrigerated storage}

It was observed, during the storage at $5^{\circ} \mathrm{C}$, a significant weight loss on day 9 , wherein the fruits lost, on average, $6.34 \%$ weight (Table 3). At the same temperature, Somboonkaew \& Terry (2011) observed weight decrease less than $2 \%$ in fruits packed in PropaFresh ${ }^{\mathrm{TM}}$ PFAM packaging for 11 days.

It was also observed significant effect of packaging, in which the fruits packed in PET trays had lower losses and the fruits stored without packaging were those with the greatest losses. Dehydration leads to loss of integrity and of the compartmentalization of the pericarp of fruits, which facilitates the occurrence of enzymatic reactions responsible for the browning of the litchi (Liang et al., 2013). The package leads to atmosphere modification and consequently increases the protection of fruits, reducing water loss and preventing or delaying their browning.

The fruits stored unpackaged showed greater peel browning, indicated by the lower luminosity, while the PET packages and the PVC film showed no significant difference, and provided lower browning (Table 3).
There was no effect of treatments on hue angle, but it was observed on chromaticity. During refrigerated storage, there was the maintenance of color, with no significant effect on the parameters $L^{*}$, Hue and Chroma. Somboonkaew \& Terry (2011) found positive results in the maintenance of the coloration of fruits of the cultivar Mauritius stored in PropaFresh ${ }^{\mathrm{TM}}$ PFAM at $5 \stackrel{\circ}{ } \mathrm{C}$. The authors highlight that the packaging was effective in preserving the anthocyanin concentration in the pericarp, keeping the red coloration.

As for appearance, fruits showed no significant decrease in the appearance score, but the fruits packed in PET tray were those who received the highest scores, while the fruits stored unpackaged had their appearance impaired (Table 3).

The greater weight loss and the greater darkening of the pericarp of fruits stored without packaging effected on the appearance of the product, consumer preference and purchase intention. It is observed, in Table 3, that the fruits packed in PET packaging were preferred by consumers, which also indicated that they would probably buy the product.

Table 3 - Weight loss, luminosity $\left(L^{*}\right)$, color (Hue angle), chromaticity (Chroma), appearance, preference and purchase intention in litchi stored under different packaging at $5^{\circ} \mathrm{C}$.

\begin{tabular}{|c|c|c|c|c|c|c|c|}
\hline Package & Weight Loss (\%) & $L^{*}$ & Hue & Chroma & Appearance & Preference & $\begin{array}{l}\text { Purchase } \\
\text { Intention }\end{array}$ \\
\hline PET & $0.14 \mathrm{C}$ & $40.52 \mathrm{~A}$ & 50.34 & $32.23 \mathrm{~A}$ & $1.78 \mathrm{C}$ & $4.35 \mathrm{~A}$ & $4.07 \mathrm{~A}$ \\
\hline PVC & $1.43 \mathrm{~B}$ & $40.64 \mathrm{~A}$ & 47.19 & $33.45 \mathrm{~A}$ & $2.33 \mathrm{~B}$ & 3.68 B & $3.52 \mathrm{~B}$ \\
\hline NO PACKAGING & $14.99 \mathrm{~A}$ & 33.89 B & 51.92 & 29.32 B & $4.00 \mathrm{~A}$ & $2.28 \mathrm{C}$ & $1.93 \mathrm{C}$ \\
\hline F Test & $2384.02^{\star \star}$ & $26.50^{* *}$ & $0.89 \mathrm{NS}$ & $10.72^{* *}$ & $108.33^{* *}$ & $407.69^{* *}$ & $268.01^{* *}$ \\
\hline MSD (5\%) & 0.61 & 2.71 & 9.23 & 2.34 & 0.40 & 0.18 & 0.23 \\
\hline \multicolumn{8}{|l|}{ Time (Days) } \\
\hline 3 & $4.85 \mathrm{~B}$ & 38.72 & 49.18 & 31.40 & 2.89 & 3.47 & $3.05 \mathrm{~A}$ \\
\hline 6 & $5.38 \mathrm{~B}$ & 38.14 & 49.45 & 31.74 & 2.56 & 3.48 & $2.97 \mathrm{~A}$ \\
\hline 9 & $6.34 \mathrm{~A}$ & 38.19 & 50.82 & 31.85 & 2.67 & 3.37 & $3.50 \mathrm{~B}$ \\
\hline F Test & $20.07^{* *}$ & $0.18 \mathrm{NS}$ & $0.12 \mathrm{NS}$ & $0.13 \mathrm{NS}$ & $2.33 \mathrm{NS}$ & $1.46 \mathrm{NS}$ & $17.98^{* *}$ \\
\hline MSD (5\%) & 0.61 & 2.71 & 9.23 & 2.34 & 0.40 & 0.18 & 0.23 \\
\hline Pack. X Time & $6.92^{* *}$ & $2.88 \mathrm{NS}$ & $0.50 \mathrm{NS}$ & $0.87 \mathrm{NS}$ & $2.33 \mathrm{NS}$ & $11.89^{* *}$ & $17.04^{* *}$ \\
\hline
\end{tabular}

Means followed by a same capital letter in the column, for each variable, do not differ significantly from each other $(P>0.05)$.

It is observed, in Table 4, which types of packaging did not affect the chemical composition of the litchi fruits. The values found for soluble solids are in agreement with those found by Hajare et al. (2010) in "Shahi" and "China" litchi. However, unlike the results obtained by the authors cited in this work, the soluble solids content did not suffer increase as a function of days of packaging. These levels have remained around $17 \stackrel{\circ}{\circ}$ Brix.

The titratable acidity levels decreased significantly during storage (Table 4 ). These results were also observed by Kumar et al. (2012), for fruits of the cultivars "Shahi" and "China" treated with sodium hypochlorite, ascorbic acid, potassium metabisulfite, hydrochloric acid and gamma irradiation, and by Salomão et al. (2012), for the cultivar "Bengal", in treatments with fruits immersed in different concentrations of hydrochloric acid and packaging in polystyrene trays covered with PVC.
The significant increase observed in the values of the SS/TA ratio (Table 4) was also found by Hojo et al. (2011), and reflected the maintenance of the soluble solids content and the decrease in the titratable acidity levels.

The $\mathrm{pH}$ values were unchanged in the fruit storage period (Table 4), unlike Kumar et al. (2012), who observed a slight increase in the values during storage.

It were not observed, in this study, losses in the ascorbic acid content, as reported by Matias et al. (2012), which in tests with fruits of the cultivar "Bengal" immersed in hot water found that the ascorbic acid content decreased over time in all treatments. According to Pandey et al. (2013), the decrease of this nutrient is due to the biochemical processes occurring after the fruit ripening, increasing deterioration. 
Table 4 - Soluble solids (SS) content, titratable acidity (TA) SS/TA ratio, $\mathrm{pH}$ and ascorbic acid (AA) in litchi stored under different packaging at $5^{\circ} \mathrm{C}$.

\begin{tabular}{|c|c|c|c|c|c|}
\hline Package & $\begin{array}{c}\text { SS } \\
\text { (知rix) }\end{array}$ & $\begin{array}{c}\text { TA } \\
\left(\mathrm{g} 100 \mathrm{~g}^{-1}\right)\end{array}$ & $\mathrm{SS} / \mathrm{TA}$ & $\mathrm{pH}$ & 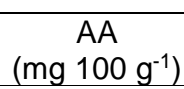 \\
\hline PET & 17.46 & 0.64 & 27.63 & 3.97 & 62.29 \\
\hline $\begin{array}{l}\text { PVC } \\
\text { NO PACKAGING }\end{array}$ & $\begin{array}{l}17.31 \\
17.22\end{array}$ & $\begin{array}{l}0.66 \\
0.62\end{array}$ & $\begin{array}{l}26.78 \\
28.06\end{array}$ & $\begin{array}{l}3.96 \\
3.97\end{array}$ & $\begin{array}{l}62.38 \\
60.83\end{array}$ \\
\hline $\begin{array}{l}\text { F Test } \\
\text { MSD (5\%) }\end{array}$ & $\begin{array}{l}0.24 \mathrm{NS} \\
0.87\end{array}$ & $\begin{array}{l}0.81 \mathrm{NS} \\
0.08\end{array}$ & $\begin{array}{l}0.69 \mathrm{NS} \\
2.83\end{array}$ & $\begin{array}{l}0.02 \mathrm{NS} \\
0.16\end{array}$ & $\begin{array}{l}0.13 \text { NS } \\
8.87\end{array}$ \\
\hline \multicolumn{6}{|l|}{ Time (Days) } \\
\hline 3 & 17.30 & $0.71 \mathrm{~A}$ & $24.65 \mathrm{~B}$ & 3.93 & 62.50 \\
\hline 6 & 17.17 & $0.60 \mathrm{~B}$ & $28.87 \mathrm{~A}$ & 3.97 & 64.56 \\
\hline 9 & 17.52 & $0.61 \mathrm{~B}$ & $28.95 \mathrm{~A}$ & 4.00 & 58.45 \\
\hline F Test & $0.55 \mathrm{NS}$ & $10.13^{\text {** }}$ & 9.86 ** & $0.62 \mathrm{NS}$ & $1.60 \mathrm{NS}$ \\
\hline MSD (5\%) & 0.87 & 0.08 & 2.83 & 0.16 & 8.87 \\
\hline Pack. X Time & $0.67 \mathrm{NS}$ & $1.34 \mathrm{NS}$ & $0.74 \mathrm{NS}$ & $0.32 \mathrm{NS}$ & $1.38 \mathrm{NS}$ \\
\hline
\end{tabular}

Means followed by a same capital letter in the column, for each variable, do not differ significantly from each other $(P>0.05)$.

\section{Conclusions}

The use of PET packaging and refrigeration in litchi storage provides better maintenance of the physical, chemical and sensory quality of the fruits for up to 9 days. In addition, this packaging is well accepted by the consumer.

\section{Acknowledgments}

To Mr Tadeu Sequaline for donating the litchi fruits used for the execution of the experiment and to the Federal Institute of Science, Education and Technology of the South of Minas Gerais Muzambinho Campus for providing all the necessary materials to perform the analyses.

\section{References}

AOAC - Association of Official Analytical Chemistry (2012). Official methods of analysis. 19th ed. Gaithersburg. 3000p.

Hajare SN, Saxena S, Kumar S, Wadhawan S, More V, Mishra BB, Parte MN, Gautan S, Sharma A (2010) Quality profile of litchi (Litchi chinensis) cultivars from India and effect of radiation processing. Radiation Physics and Chemistry 79:994-1004.

Hojo ETD, Durigan JF, Hojo RH (2011) Uso de Embalagens Plásticas e Cobertura de Quitosana na Conservação Pós-Colheita de Lichias. Revista Brasileira de Fruticultura 33(n. spe 1):377-383.

Kaushik N, Kaur BP, Rao PS (2013) Application of high pressure processing for shelf life extension of litchi fruits (Litchi chinensis cv. Bombai) during refrigerated storage. Food Science and Technology International 19(4):1-15.
Kumar S, Mishra BB, Saxena S, Bandyopadhyay N, More V, Wadhawan S, Hajare S,N, Gautan S, Sharma A (2012) Inhibition of pericarp browning and shelf life extension of litchi by combination dip treatment and radiation processing. Food Chemistry 131:1223-1232.

Liang YS, Wongmetha O, Wu PS, Ke LS (2013) Influence of hydrocooling on browning and quality of litchi cultivar Feizixiao during storage. International Journal of Refrigeration 36:1173-1179.

Lima RAZ, Abreu CMP, Asmar AS, Correa AD, Santos CD (2010) Embalagens e recobrimento em lichias (Litchi chinensis Sonn.) armazenadas sob condições não controladas. Ciência e Agrotecnologia 34( 4):914-921.

Liu H, Song L, You Y, Li Y, Duan X, Jiang Y, Joyce DC, Ashraf M, Lu W (2011) Cold storage duration affects litchi fruit quality, membrane permeability, enzyme activities and energy charge during shelf time at ambient temperature. Postharvest Biology and Technology 60:24-30.

Martins ABG (2005) Lichia. Revista Brasileira de Fruticultura 27(3):349-520.

Matias RGP, Silva DFP, Lins LCR, Alves RR, Salomão LCC (2012) Tratamento Hidrotérmico na Prevenção do Escurecimento do Pericarpo de Lichia. Revista Brasileira de Agropecuária Sustentável 2(1):68-75.

Meilgaard M, Civille GV, Carr BT (1999) Sensory evaluation techniques. London: CRC. $387 \mathrm{p}$.

Pandey N, Joshil SK, Singh CP, Kumar S, Rajput S, Khangal RK (2013) Enhancing shelf life of litchi (Litchi chinensis) fruit through integrated approach of surface coating and gamma irradiation. Radiation Physics And Chemistry 85:197-203.

Reis RC, Minim VPR (2006) Teste de aceitação. In: MINIM, V. P. R. (Ed). Análise sensorial: estudos com consumidores. Viçosa: Editora. UFV. p. 66-83. 
Salomão LCC, Silva DFP, Rocha A, Alves RR, Matias RGP (2012) Redução do Escurecimento do Pericarpo de Lichia com Ácido Clorídrico. Revista Brasileira de Fruticultura 34(2):568-575.

Silva DFP, Cabrini EC, Alves RR, Salomão LCC (2010) Uso do ácido ascórbico no controle do escurecimento do pericarpo da lichia. Revista Brasileira de Fruticultura 32(2):618-627.
Silva DFP, Lins LCR, Cabrini EC, Brasileiro BG, Salomão LCC (2012) Influence of the use of acids and films in post-harvest lychee conservation. Revista Ceres 59(6):745-750.

Somboonkaew N, Terry LA (2011) Influence of temperature and packaging on physiological and chemical profiles of imported litchi fruit. Food Research International 44:1962-1969. 